\title{
Bio Efficacy of Some Commercially Available Eco-Friendly Insecticides against Diamondback Moth, Plutella xylostella L. in Cabbage
}

\author{
M. Vignesh ${ }^{1 *}$, J. Murasing ${ }^{2}$ and Ibohal Singh ${ }^{2}$ \\ ${ }^{1}$ Department of Agricultural Entomology, University of Agricultural Sciences, \\ Dharward, Karnataka, India \\ ${ }^{2}$ Department of Agricultural Entomology, Central Agricultural University, \\ Imphal, Manipur, India \\ *Corresponding author
}

\begin{tabular}{|c|c|}
\hline \multicolumn{2}{|r|}{ A B S T R A C T } \\
\hline & \multirow{5}{*}{$\begin{array}{l}\text { Cabbage (Brassica oleracea } \mathrm{L} \text {. var capitata) is one of the most important cruciferous green } \\
\text { leaf vegetables grown extensively in tropical and temperate regions of the world. Cabbage } \\
\text { crop is attacked by a number of insect pests. Of these, diamond back moth, Plutella } \\
\text { xylostella has become serious pest from sowing to harvest. To mitigate the losses, farmers } \\
\text { use large quantities of pesticides. Indiscriminate use of pesticides has led to many } \\
\text { problems like insecticide resistance, resurgence and residues. Keeping this in view, } \\
\text { investigations were undertaken to test the commercially available six ecofriendly } \\
\text { pesticides against } P \text {. xylostella. The pooled mean results of these sprays are presented as } \\
\text { follows. Among the different eco-friendly insecticides evaluated against } P \text {. xylostella, the } \\
\text { Refresh @ } 750 \mathrm{ml} / \mathrm{ha} \text { and Signature @ } 750 \mathrm{ml} / \mathrm{ha} \text { closely performed well with the least leaf } \\
\text { damage percentage of } 6.9 \text { and } 8.4 \text { percentage, respectively which is followed by } \\
\text { Dichlorvos } 76 \mathrm{SL} @ 500 \mathrm{ml} / \mathrm{ha} \text { with } 10.53 \text { percentage leaf damage. The three insecticides } \\
\text { (Refresh, Signature, Dichlorvos) were statistically on par. Bio Dose Magnum @ } 750 \mathrm{ml} / \mathrm{ha} \\
\text { proved the least effective one among eco-friendly insecticides recording the mean leaf } \\
\text { damage percentage of } 13.59 \text {. However all the eco-friendly insecticides tested exhibited } \\
\text { statistically better than the untreated control (34.55\% LD). The highest yield of } 24.07 \mathrm{t} / \mathrm{ha} \\
\text { obtained from the Refresh treated plots followed by Signature }(23.53 \mathrm{t} / \mathrm{ha} \text { ). The cost- } \\
\text { benefit ratios varied from } 1: 5.8 \text { to } 1: 24.4 \text { in different insecticidal treatments. Dichlorvos } \\
\text { gave the maximum monetary benefit with highest cost-benefit ratio }(1: 24.4) \text { followed by } \\
\text { Refresh with a recorded monetary cost-benefit ratio of } 1: 18.5 \text {, respectively. }\end{array}$} \\
\hline & \\
\hline Article I & \\
\hline & \\
\hline & \\
\hline
\end{tabular}

\section{Introduction}

In Manipur, the total area under cabbage is only 3985 ha with a production of 50,939 M.T. as against the national production of 5,617.1 thousand M.T from an area of 245.4 thousand hectares. Thus, the productivity is only 10.1 M.T/ha in Manipur as compared to the national productivity of $22.89 \mathrm{M} . \mathrm{T} / \mathrm{ha}$ (FAO, 2012 and Anon., 2012). The reason for this low yield can be attributed to the attack of the cabbage crops by insect pests coupled with lack of a proper and scientific study on the nature and control of such pests.

In India a total of 37 insect pests have been reported to feed on cabbage of which the diamond back moth, Plutella xylostella 
(Linn.) (Lepidoptera: Plutellidae) is one of the major constraints for profitable cultivation of the crop (Lal, 1975).

In many of the countries, the diamond back moth has developed resistance to every synthetic insecticides used against it in the field (Talekar et al., 1990) and is well on its way to develop multiple resistance in India (Mehrotra, 1993). This has necessitated the use of alternative eco-friendly insecticides to sustain the management of DBM.

Bio-pesticide ensures effectiveness, safety and acceptability to mankind. Therefore, certain eco-friendly insecticides were evaluated for their efficacy against diamond back moth of cabbage under field conditions.

\section{Materials and Methods}

A field trial was carried out in randomized block design (RBD) with 9 treatments including Bio Dose magnum @ 750ml/ha, Green Pacer @ 2500g/ha, Bio M power @ $750 \mathrm{ml} / \mathrm{ha}$, Dichlorovos 76SL @ $500 \mathrm{ml} / \mathrm{ha}$, Refresh@750 ml/ha, Signature @ 750 ml/ha, Green Focus @ 1000 ml/ha and untreated control replicated three times.

The test variety "Pride of India" was planted at $40 \times 50 \mathrm{~cm}$ spacing in plot size of $20 \mathrm{sq} . \mathrm{m}$ (4 $x 5 \mathrm{~m})$. The relative field efficacy of the test insecticides was determined by recording the leaf damaging percentage of diamond back moth at one day before and 3, 7 and 10 days after each application of insecticides from five randomly selected tagged plants in each plot.

\section{Determination of avoidable yield loss and cost-benefit ratio}

The avoidable yield loss was computed in each treatment by using the formula suggested by Pawar et al., (1994).
Percent avoidable yield loss $=\frac{\text { C-T }}{\text { C }} \times 100$

Where,

$\mathrm{T}=$ Yield in most effective treatment

$\mathrm{C}=$ Yield in respective treatment

The monetary benefit was estimated by deducting the cost of insecticides, pump hiring and labour charges from the cost of additional yield obtained over untreated control.

\section{Statistical analysis}

The data obtained from different experiments are computed to determine the mean values. The mean values after suitable transformation is subjected to statistical analysis to test significance as per the Analysis of Variance for interpretation of the results.

\section{Results and Discussion}

The results of the study on the extent of leaf damage in different insecticidal treatments revealed that all the test compounds were significantly superior to untreated control in reducing the extent of damage at 3, 7 and 10 days after application.

Observations recorded at one day before application of insecticides did not show any significant difference in the extent of leaf damage (Table1).

\section{Extent of leaf damage at 3 days after application (DAA)}

The extent of leaf damage recorded at $3 \mathrm{DAA}$ ranged from $5.86-11.77$ per cent in insecticidal treatments as against 31.34 per cent in untreated control. Refresh recorded the least extent of leaf damage (5.86 per cent) 
followed by signature (7.53 per cent) and Dichlorvos (10.23 per cent), which had nonsignificant difference from each other (Table $4)$. The highest leaf damage incidence (11.77 per cent) was marked in the plots treated with Bio-M-Power.

\section{Extent of leaf damage at 7 DAA}

The data on the extent of leaf damage recorded during experimental year of 2014-15 (Tables 1) indicated that at 7 DAA, Refresh maintained its superiority in suppression of the pest recording the minimum leaf damage of 6.80 per cent as against 35.53 per cent in untreated control.

The effectiveness of Refresh was at par with that of Signature and Dichlorvos with a record of mean leaf damage incidence of 8.35 and 10.42 per cent, respectively. The maximum mean extent of leaf damage (14.11 per cent) was observed in the treatment with Bio-DoseMagnum. However, the extent of damage was significantly lower in the plots treated with insecticides as compared to untreated control plots.

\section{Extent of leaf damage at 10 DAA}

The data on the extent of damage recorded during Rabi season of 2014-15 at 10 DAA varied from 8.04 to 14.95 per cent in insecticidal treatments as against 36.8 per cent in untreated control (Table 1).

The same trend in efficacy of Refresh against DBM was noticed as observed at 7 DAA recording the lowest extent of leaf damage of 8.04 per cent and was followed by signature (9.33 per cent) and Dichlorvos (10.94 per cent) which did not differ significantly from one another.

While Bio-Dose-Magnum recorded highest leaf damage (14.95 per cent). However, the extent of leaf damage was significantly lower in the plots treated with insecticides than that of untreated control plots.

\section{Mean leaf damage over three sprays based on three observation intervals}

The pooled mean per cent damaged leaves data of three sprays presented in Table 1 and illustrated in Fig. 1 revealed that the minimum per cent damaged leave was recorded in plots treated with Refresh @750 $\mathrm{ml} / \mathrm{ha}$ with mean per cent damaged leaves of 6.90 per cent as against 34.55 percent leaf damage in untreated control plots. It was closely followed by Signature @750 ml/ha with mean per cent damaged leaves of 8.40 per cent and Dichlorvos 76 SL @ 500 ml/ha with mean per cent damaged leaves of 10.53 per cent but had no significant difference from each other. Among the insecticidal treatments Bio-Dose-Magnum @750 ml/ha showed least effectiveness against the pest with a record of maximum per cent mean damaged leaves of 13.59 per cent. The effectiveness of rest insecticides varied from 12.15 to 13.06 per cent leaf damage which minimum being recorded in the plots of Green Pacer and maximum in Bio-M-Power treated plots. The order of efficacy of each of treatments along with the test of significance is depicted below:

Refresh, Signature, Dichlorvos, Green Pacer, Green Focus, Bio-M-Power, Bio-Dose-Magnum, Control.

\section{Effect of eco-friendly insecticidal treatments on yield of cabbage}

The mean yield data of Cabbage var. 'Pride of India' yield presented in Table 2 indicated that the minimum yield (13.04 $\left.\mathrm{t} \mathrm{ha}^{-1}\right)$ was obtained from untreated control plots which was significantly lower than the yields harvested from the insecticidal treated plots. 
Table.1 Effect of eco-friendly insecticides on leaf damage due to diamond back moth on cabbage

\begin{tabular}{|c|c|c|c|c|c|c|c|c|c|}
\hline \multirow[t]{2}{*}{ Treatment } & \multirow{2}{*}{\begin{tabular}{|l|} 
Dose \\
per \\
hectare
\end{tabular}} & \multicolumn{3}{|c|}{ Mean leaf damage (\%) during } & \multirow[t]{2}{*}{ Pooled Mean } & \multirow[t]{2}{*}{ 1DBA } & \multicolumn{3}{|c|}{$\begin{array}{l}{ }^{1} \text { Composite mean leaf damage over } 1^{\text {st, }} 2^{\text {nd }} \\
\text { spray and } 3^{\text {rd }} \text { spray }\end{array}$} \\
\hline & & $1^{\text {st }}$ spray & $2^{\text {nd }}$ spray & $3^{\text {rd }}$ spray & & & 3DAA & 7DAA & 10DAA \\
\hline $\begin{array}{l}\mathrm{T}_{1}=\text { Bio Dose } \\
\text { Magnum }\end{array}$ & $750 \mathrm{ml}$ & $19.33(26.06)$ & $13.46(21.47)$ & $13.46(21.47)$ & $13.59(21.56)$ & $21.40(27.56)$ & $11.71(20.00)$ & $14.11(22.06)$ & $14.95(22.71)$ \\
\hline $\begin{array}{l}\mathrm{T}_{2}=\text { Bio } \mathrm{M} \\
\text { Power }\end{array}$ & $750 \mathrm{ml}$ & $20.11(26.64)$ & $11.08(20.09)$ & $11.08(20.09)$ & $13.06(21.22)$ & $21.30(27.49)$ & $11.77(20.09)$ & $13.25(21.30)$ & $14.18(22.14)$ \\
\hline $\mathrm{T}_{3}=$ Refresh & $750 \mathrm{ml}$ & $18.22(25.25)$ & 11.51(19.82) & $11.51(19.82)$ & $6.9(15.23)$ & 20.93(27.20) & $5.86(14.06)$ & $6.8(15.12)$ & $8.04(16.43)$ \\
\hline $\mathrm{T}_{4}=$ Signature & $750 \mathrm{ml}$ & $11.74(20)$ & $7.06(15.34)$ & $7.06(15.34)$ & $8.4(16.85)$ & $20.89(27.13)$ & $7.53(15.89)$ & $8.35(16.74)$ & $9.33(17.76)$ \\
\hline $\begin{array}{l}\mathrm{T}_{5}=\text { Green } \\
\text { Focus }\end{array}$ & $1000 \mathrm{ml}$ & $14.11(22.06)$ & $13.36(21.39)$ & $13.36(21.39)$ & $12.41(20.62)$ & $20.83(27.15)$ & $11.57(19.91)$ & $12.17(20.44)$ & $13.5(21.56)$ \\
\hline $\begin{array}{l}\mathrm{T}_{6}=\text { Green } \\
\text { Pacer }\end{array}$ & $2500 \mathrm{~g}$ & $15.53(23.13)$ & $8.66(17.05)$ & $8.66(17.05)$ & $12.15(20.36)$ & $20.36(26.78)$ & $11.15(19.46)$ & $12.21(20.48)$ & $13.11(21.22)$ \\
\hline $\begin{array}{l}\mathrm{T}_{7}= \\
\text { Dichlorvos } 76 \\
\text { SL }\end{array}$ & $500 \mathrm{ml}$ & 6.21(14.42) & $6.3(14.54)$ & $6.3(14.54)$ & $10.53(18.91)$ & $15.43(23.11)$ & $10.23(18.63)$ & $10.42(18.81)$ & $10.94(19.28)$ \\
\hline $\begin{array}{l}\mathrm{T}_{0}=\text { Control } \\
\text { (water) }\end{array}$ & - & $26.05(30)$ & $35.95(36.81)$ & $35.95(36.81)$ & $34.55(35.97)$ & $20.00(26.57)$ & $31.34(34.02)$ & $35.53(36.57)$ & $36.8(37.35)$ \\
\hline S.E.d \pm & - & 2.77 & 1.68 & 1.68 & 1.93 & NS & 1.6 & 2.89 & 1.3 \\
\hline C.D $(\mathrm{P}=0.05)$ & - & 4.77 & 3.61 & 3.61 & 3.83 & NS & 3.5 & 4.8 & 3.2 \\
\hline
\end{tabular}

(Composite means of 3 observations recorded at 3,7 and 10 days after application.)

Figures in parentheses are Arc Sin percentage

Table.2 Yield increase percentage over control

\begin{tabular}{|l|l|l|l|l|}
\hline \multirow{2}{*}{ Treatment } & Dose & \multirow{2}{*}{$\begin{array}{l}\text { Yield } \\
(\mathbf{t} / \mathbf{h a})\end{array}$} & \multicolumn{2}{l|}{ Yield increase over control } \\
\cline { 4 - 5 } & & & $(\mathbf{t} / \mathbf{h a})$ & Percentage \\
\hline $\mathrm{T}_{1}=$ Bio Dose Magnum & $750 \mathrm{ml} / \mathrm{ha}$ & 18.95 & 5.91 & 45.53 \\
\hline $\mathrm{T}_{2}=$ Bio M Power & $750 \mathrm{ml} / \mathrm{ha}$ & 20.61 & 7.57 & 58.05 \\
\hline $\mathrm{T}_{3}=$ Refresh & $750 \mathrm{ml} / \mathrm{ha}$ & 24.07 & 11.03 & 84.45 \\
\hline $\mathrm{T}_{4}=$ Signature & $750 \mathrm{ml} / \mathrm{ha}$ & 23.53 & 10.49 & 80.44 \\
\hline $\mathrm{T}_{5}=$ Green Focus & $1000 \mathrm{ml} / \mathrm{ha}$ & 21.27 & 8.23 & 63.11 \\
\hline $\mathrm{T}_{6}=$ Green Pacer & $2500 \mathrm{~g} / \mathrm{ha}$ & 20.77 & 7.73 & 59.27 \\
\hline $\mathrm{T}_{7}=$ Dichlorvos $76 \mathrm{SL}$ & $500 \mathrm{ml} / \mathrm{ha}$ & 22.01 & 8.97 & 68.78 \\
\hline $\mathrm{To}=$ control & - & 13.04 & - & - \\
\hline
\end{tabular}


Table.3 Avoidable yield loss (\%) of cabbage in different eco-friendly insecticidal treatments on cabbage during Rabi season of 2014-15

\begin{tabular}{|l|c|c|}
\hline \multicolumn{1}{|c|}{ Treatments } & Dose & Avoidable yield loss (\%) \\
\hline $\mathrm{T}_{1}=$ Bio Dose Magnum & $750 \mathrm{ml} / \mathrm{ha}$ & $21.27(27.49)$ \\
\hline $\mathrm{T}_{2}=$ Bio M Power & $750 \mathrm{ml} / \mathrm{l}$ & $14.37(22.3)$ \\
\hline $\mathrm{T}_{4}=$ Signature & $750 \mathrm{ml} / 1$ & $2.24(8.53)$ \\
\hline $\mathrm{T}_{5}=$ Green Focus & $750 \mathrm{ml} / 1$ & $11.63(19.91)$ \\
\hline $\mathrm{T}_{6}=$ Green Pacer & $1000 \mathrm{ml} / 1$ & $13.71(21.72)$ \\
\hline $\mathrm{T}_{7}=$ Dichlorvos 76SL & $2500 \mathrm{~g} / \mathrm{ha}$ & $8.5(16.05)$ \\
\hline $\mathrm{T}_{0}=$ Control (water) & $500 \mathrm{ml} / \mathrm{ha}$ & $45.82(42.65)$ \\
\hline S.E.d \pm & & 1.73 \\
\hline C.D $(\mathrm{P}=0.05)$ & & 2.52 \\
\hline
\end{tabular}

Fig.1 Graphical representation of leaves damage by DBM in various treatments

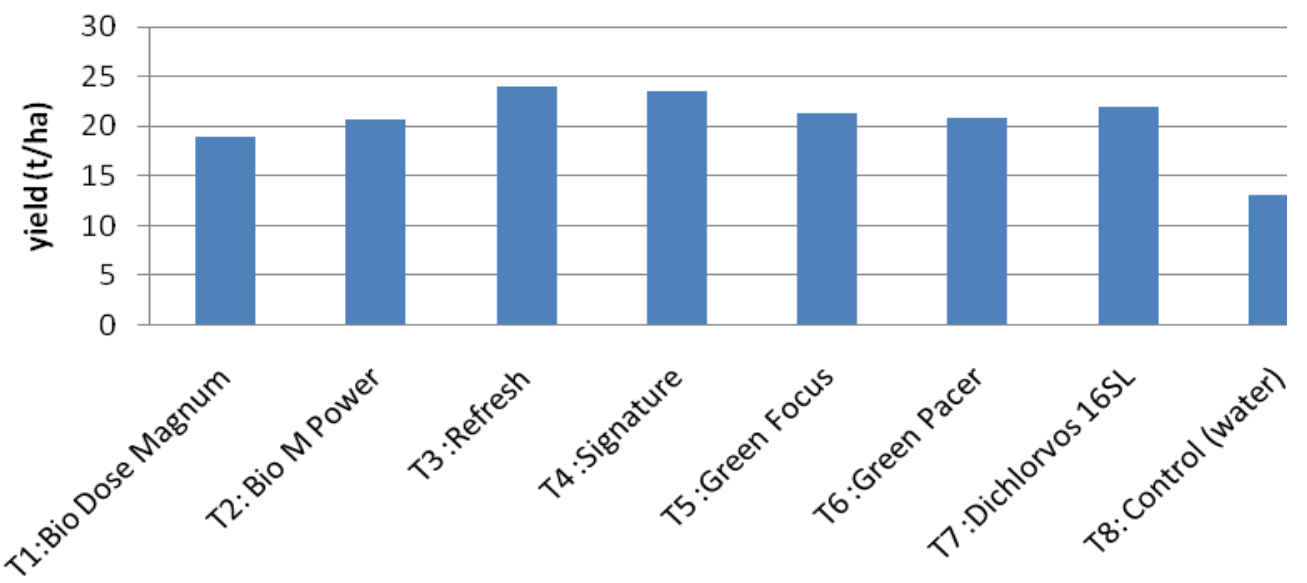

Ttreatments

The yield ranged from $20.61-24,07$ t/ha and the Refresh treated plots recorded the highest yield of $24.07 \mathrm{t} / \mathrm{ha}$ with maximum yield increase over control of $11.03 \mathrm{t} \mathrm{ha}^{-1}$ and 84.45 per cent, and lowest $\left(18.95 \mathrm{t} \mathrm{ha}^{-1}\right)$ in BioDose-Magnum treatment with minimum yield increase of $5.91 \mathrm{t} \mathrm{ha}^{-1}$ and 45.53 per cent. The yield of Refresh was followed by Signature (23.53 $\mathrm{t} \mathrm{ha}^{-1}$ ) with yield increase over control of $10.49 \mathrm{t} / \mathrm{ha}^{-1}$ and 80.44 per cent and Dichlorvos (22.01 $\mathrm{t} \mathrm{ha}^{-1}$ ) exhibiting yield increase over control of $8.97 \mathrm{t} \mathrm{ha}^{-1}$ and 68.78 per cent which had no significant difference from one another. The mean cabbage yield harvested from the plots of other insecticidal treatments varied from 18.95 (Bio-DoseMagnum) to $21.27 \mathrm{t} \mathrm{ha}^{-1}$ (Green Focus) with increase yield over control of $5.91-8.23 \mathrm{t}$ $\mathrm{ha}^{-1}$ and 45.53 - 63.11 percent.

\section{Avoidable yield loss and cost benefit ratio of different insecticidal treatments}

Considering maximum realizable yield in Refresh treatment (24.07 $\mathrm{t} \mathrm{ha}^{-1}$ ) which also afforded maximum protection of the crop from P.xylostella infestation, the avoidable yield loss was computed to be 45.82 per cent 
in the untreated control plots (Table 3). Application of insecticides resulted in reduction of the mean avoidable loss, which ranged between 2.24 and 21.27 per cent in different insecticidal treatments, the lowest being in Refresh and highest in Bio-DoseMagnum.

Cost effectiveness of various insecticides in controlling the moth is calculated which showed that Refresh gave the maximum net profit of Rs. 1,04,660.00 with the cost benefit ratio of 1:18.50. Dichlorvos 76 SL treatment also recorded the higher cost benefit ratio of 1:24.40 with higher net profit of Rs. 86,177.00. The Bio-Dose-Magnum treatment gave minimum net profit of Rs. 54,360.00 with the lowest cost benefit ratio (1:11.40). For each one rupee invested on application of rest of the test insecticides, there was monetary benefit of Rs. 18.50 (Refresh) to Rs. 5.80 (Bio-M-Power).

Among the different commercially available eco-friendly insecticides comprising of six natural products (Bio Dose Magnum, Bio M Power, Refresh, Signature, Green Focus, Green Pacer) eco-friendly insecticides and one synthetic organic product (Dichlorvos 76 SL) evaluated, Refresh @ $750 \mathrm{ml} / \mathrm{ha}$ gave the highest mortality of the DBM and was found to be the most effective treatment with a record of minimum leaf damage percentage due to DBM of $6.9 \%$. It was followed by Signature @ $750 \mathrm{ml} / \mathrm{l}$ and Dichlorvos 76SL @ $500 \mathrm{ml} /$ ha with their corresponding mean leaf damage percentage of 8.4 and 10.53 percentage, respectively but not showed a significant difference from one another. The maximum leaf damage (13.59 \%) was recorded in plots treated with Bio Dose Magnum @1.5 m1/l.

However, all the eco-friendly insecticides used have shown statistically better than the untreated control $(34.55 \%$ LD). So the future studies should be focused on the effect of those chemicals used in the current study on the natural enemies which could enable us to form the IPM in cabbage by incorporating the tested chemicals effectively.

\section{References}

Anonymous, (2012). Indian Horticulture Database 2002, National Horticulture Board, Ministry of Agriculture, Govt. of India.

FAO (2012) Crop Cultures. FAO Quarterly Bulletin of statistics: 12(3/4): 73-76.

Lal, O.P. (1975). A compendium of insect pests of vegetables in India. Bull. Entomol, 16:51-56.

Mehrotra, K.N. (1993). Pesticide resistance in India. In Chemistry and Industry, 399403.

Pawar, V.M., Shirshikar, S.P. and Yadav, G.D. (1984). Relative efficiency and economics of acephate for the control of bollworms. Indian J. Pl.Prot., 12: 4347.

Talekar, N.S., Yang, J.C. and Lee, S.T. (1990). Annotated Bibliography of Diamond back moth, vol. 2. Asian Vegetable Research and Development Centre, Taiwan. 199 pp.

\section{How to cite this article:}

Vignesh M., J. Murasing and Ibohal Singh. 2017. Bio Efficacy of Some Commercially Available Eco-Friendly Insecticides against Diamondback Moth, Plutella xylostella L. in Cabbage. Int.J.Curr.Microbiol.App.Sci. 6(10): 4948-4953.

doi: https://doi.org/10.20546/ijcmas.2017.610.468 